ఠ

CORRIGENDUM

\title{
Effect of 6 months of whole body vibration on lumbar spine bone density in postmenopausal women: a randomized controlled trial [Corrigendum]
}

\author{
Lai CL, Tseng SY, Chen CN, et al. Clin Interv Aging. \\ 2013;8:1603-1609.
}

On page 1603, the author affiliations have been listed incorrectly. The correct author list is as follows:

\section{Chung-Liang Lai ${ }^{1,2,6}$ \\ Shiuan-Yu Tseng ${ }^{1,2}$ \\ Chung-Nan Chen ${ }^{3}$ \\ Wan-Chun Liao ${ }^{2}$ \\ Chun-Hou Wang ${ }^{4}$ \\ Meng-Chih Lee ${ }^{1,5, *}$ \\ Pi-Shan $\mathrm{Hsu}^{5, *}$}

'Institute of Medicine, Chung Shan Medical University, Taichung, Taiwan; ${ }^{2}$ Department of Physical Medicine and Rehabilitation,

Taichung Hospital, Ministry of Health and Welfare, Taichung,

Taiwan; ${ }^{3}$ Department of Radiology, Taichung Hospital, Ministry of Health and Welfare, Taichung, Taiwan; ${ }^{4}$ School of Physical Therapy, Chung Shan Medical University, Taichung, Taiwan; ${ }^{5}$ Department of Family Medicine, Taichung Hospital, Ministry of Health and Welfare, Taichung, Taiwan; ${ }^{6}$ Central Taiwan University of Science and

Technology, Taichung, Taiwan

\section{Publish your work in this journal}

Clinical Interventions in Aging is an international, peer-reviewed journal focusing on evidence-based reports on the value or lack thereof of treatments intended to prevent or delay the onset of maladaptive correlates of aging in human beings. This journal is indexed on PubMed Central, MedLine,
CAS, Scopus and the Elsevier Bibliographic databases. The manuscript management system is completely online and includes a very quick and fair peer-review system, which is all easy to use. Visit http://www.dovepress. com/testimonials.php to read real quotes from published authors. 